\section{Contemporary Issues in Group Learning in Undergraduate Science Classrooms: A Perspective from Student Engagement}

\author{
Linda C. Hodges* \\ Faculty Development Center, University of Maryland, Baltimore County, Baltimore, MD 21250
}

\begin{abstract}
As the use of collaborative-learning methods such as group work in science, technology, engineering, and mathematics classes has grown, so has the research into factors impacting effectiveness, the kinds of learning engendered, and demographic differences in student response. Generalizing across the range of this research is complicated by the diversity of group-learning approaches used. In this overview, I discuss theories of how group-work formats support or hinder learning based on the ICAP (interactive, constructive, active, passive) framework of student engagement. I then use this model to analyze current issues in group learning, such as the nature of student discourse during group work, the role of group learning in making our classrooms inclusive, and how classroom spaces factor into group learning. I identify key gaps for further research and propose implications from this research for teaching practice. This analysis helps identify essential, effective, and efficient features of group learning, thus providing faculty with constructive guidelines to support their work and affirm their efforts.
\end{abstract}

\section{INTRODUCTION}

Group work is a common active-learning practice in biology and other science, technology, engineering, and mathematics (STEM) classes. In general, active-learning approaches engage students in applying and processing ideas rather than just listening (for examples, see Hodges, 2015; Kober, 2015; Felder and Brent, 2016). Active learning, such as group work, has been shown to result in better student learning outcomes (Hake, 1998; Springer et al., 1999; Freeman et al., 2014) and more positive student attitudes (Vernon and Blake, 1993; Springer et al., 1999). In the meta-analysis of research on active learning conducted by Freeman et al. (2014), the positive impact of active-learning pedagogies was clear enough that the authors proposed that, rather than continue to compare the results of traditional lecturing and active learning, research should focus more on how and for whom active learning is most effective.

Indeed, as the use of collaborative-learning methods such as group work has grown, so has the research into factors impacting effectiveness, the kinds of learning engendered, and demographic differences in student response. Generalizing across the range of this research is often complicated by the diversity of group-work approaches used. In this overview, I discuss theories of how group work supports or hinders learning based on the ICAP (interactive, constructive, active, passive) framework of student engagement (Chi, 2009; Chi and Wylie, 2014). I then use this model to analyze current issues in group learning. I also propose implications for teaching practice and further research.

\section{BRIEF DESCRIPTIONS OF GROUP-LEARNING FORMATS}

Different implementations of group learning currently in the literature include cooperative learning, collaborative learning, peer discussion, peer-led team learning (PLTL), peer instruction (PI), problem-based learning (PBL), team-based learning (TBL), and
Peggy Brickman, Monitoring Editor Submitted November 15, 2017; Revised February 15, 2018; Accepted February 22, 2018 CBE Life Sci Educ June 1, 2018 17:es3 DOI:10.1187/cbe.17-11-0239

*Address correspondence to: Linda C. Hodges (lhodges@umbc.edu).

๑) 2018 L. C. Hodges. CBE-Life Sciences Education @ 2018 The American Society for Cell Biology. This article is distributed by The American Society for Cell Biology under license from the author(s). It is available to the public under an Attribution-Noncommercial-Share Alike 3.0 Unported Creative Commons License (http://creativecommons.org/licenses/ by-nc-sa/3.0).

"ASCB" ${ }^{\oplus "}$ and "The American Society for Cell Biology ${ }^{\circledR "}$ are registered trademarks of The American Society for Cell Biology. 
TABLE 1. Key characteristics of common group-learning formats

\begin{tabular}{|c|c|c|c|c|}
\hline Format & $\begin{array}{l}\text { How groups are used in } \\
\text { class }\end{array}$ & How groups are formed & What groups do & How groups are assessed \\
\hline \multicolumn{5}{|c|}{ Informal group formats } \\
\hline $\begin{array}{l}\text { Collaborative/ } \\
\text { cooperative } \\
\text { learning }\end{array}$ & Intermittently & $\begin{array}{l}\text { Self-selected or instructor } \\
\text { formed, with students } \\
\text { possibly assuming } \\
\text { rotating roles }\end{array}$ & $\begin{array}{l}\text { Address questions or } \\
\text { problems to process } \\
\text { ideas in class }\end{array}$ & $\begin{array}{l}\text { Occasional in-class work for a } \\
\text { group grade or participation } \\
\text { points (optional) }\end{array}$ \\
\hline Peer discussion & Intermittently & $\begin{array}{l}\text { Self-selected groups of } \\
\text { neighboring students }\end{array}$ & $\begin{array}{l}\text { Address questions or } \\
\text { problems to process } \\
\text { ideas in class }\end{array}$ & $\begin{array}{l}\text { Occasional in-class work for a } \\
\text { group grade or participation } \\
\text { points (optional) }\end{array}$ \\
\hline \multicolumn{5}{|c|}{ Formal pedagogical approaches using groups } \\
\hline Peer instruction (PI) & $\begin{array}{l}\text { Consistently as the } \\
\text { primary mechanism } \\
\text { for processing content }\end{array}$ & $\begin{array}{l}\text { Self-selected groups of } \\
\text { neighboring students }\end{array}$ & $\begin{array}{l}\text { Discuss questions after } \\
\text { individual students } \\
\text { have responded using } \\
\text { polling devices; } \\
\text { students possibly } \\
\text { follow up with a revote }\end{array}$ & $\begin{array}{l}\text { Individual responses via polling } \\
\text { systems for a grade or } \\
\text { participation points (optional) }\end{array}$ \\
\hline $\begin{array}{l}\text { Problem-based learning } \\
\quad \text { (PBL) }\end{array}$ & $\begin{array}{l}\text { Consistently as the } \\
\text { primary mechanism } \\
\text { for processing content }\end{array}$ & $\begin{array}{l}\text { Instructor-formed groups } \\
\text { of four to five students, } \\
\text { with students possibly } \\
\text { assuming rotating roles }\end{array}$ & $\begin{array}{l}\text { Address complex and/or } \\
\text { real-world problems } \\
\text { over multiple sessions }\end{array}$ & $\begin{array}{l}\text { Group problem solutions for a } \\
\text { group grade; peer review }\end{array}$ \\
\hline $\begin{array}{l}\text { Team-based learning } \\
\text { (TBL) }\end{array}$ & $\begin{array}{l}\text { Consistently as the } \\
\text { primary mechanism } \\
\text { for processing content }\end{array}$ & $\begin{array}{l}\text { Instructor-formed groups } \\
\text { of four to seven } \\
\text { students }\end{array}$ & $\begin{array}{l}\text { Address application } \\
\text { questions, with all } \\
\text { groups addressing the } \\
\text { same question and } \\
\text { answering simultane- } \\
\text { ously using color-coded } \\
\text { cards }\end{array}$ & $\begin{array}{l}\text { Individual and team quizzes on } \\
\text { preparation; group application } \\
\text { exercises for a team grade } \\
\text { (optional); peer review }\end{array}$ \\
\hline $\begin{array}{l}\text { Process-oriented guided } \\
\text { inquiry (POGIL) }\end{array}$ & $\begin{array}{l}\text { Consistently, but may } \\
\text { be the primary } \\
\text { mechanism for } \\
\text { engaging with } \\
\text { selected content }\end{array}$ & $\begin{array}{l}\text { Instructor-formed groups } \\
\text { of three to four } \\
\text { students, with students } \\
\text { assuming rotating roles }\end{array}$ & $\begin{array}{l}\text { Engage with structured } \\
\text { materials to build } \\
\text { conceptual under- } \\
\text { standing from } \\
\text { examples or data }\end{array}$ & $\begin{array}{l}\text { Group problem solutions for a } \\
\text { group grade or participation } \\
\text { points (optional); group quiz } \\
\text { (optional); individual } \\
\text { follow-up quiz (optional) }\end{array}$ \\
\hline \multicolumn{5}{|c|}{ Structured group format external to class time } \\
\hline $\begin{array}{l}\text { Peer-led team learning } \\
\text { (PLTL) }\end{array}$ & $\begin{array}{l}\text { Supplemental to class } \\
\text { and usually voluntary }\end{array}$ & $\begin{array}{l}\text { Self-selected groups (by } \\
\text { registration) of six to } \\
\text { eight students with a } \\
\text { trained peer leader } \\
\text { (1-2 hours per week) }\end{array}$ & $\begin{array}{l}\text { Engage with structured } \\
\text { materials to build } \\
\text { conceptual under- } \\
\text { standing and } \\
\text { problem-solving skills }\end{array}$ & $\begin{array}{l}\text { Ungraded or graded depending on } \\
\text { whether students receive } \\
\text { separate credit; assessments (if } \\
\text { warranted) directed toward } \\
\text { preparation activities and/or } \\
\text { activities during the session }\end{array}$ \\
\hline
\end{tabular}

process-oriented guided inquiry (POGIL). I describe each of these briefly and in Table 1 .

Some of the terms used in group learning refer to formats for organizing informal, intermittent group experiences in classspecifically, collaborative learning, cooperative learning, and peer discussion. Historically, collaborative learning (Bruffee, 1999) and cooperative learning (Johnson et al., 1998; Millis and Cottell, 1998) referred to less-structured or more-structured group approaches, respectively. Over time, distinctions between these approaches blurred, and now they are often treated synonymously. "Peer discussion" is a phrase coined to describe small informal groups of students talking about content in class (Eddy et al., 2015).

The four formal group -work pedagogies include PI (Mazur, 1997), PBL (Wilkerson and Gijselaers, 1996), TBL (Michaelsen et al., 2004), and POGIL (Moog and Spencer, 2008). In PI, classroom instruction centers primarily on instructors asking students conceptual questions that students answer using classroom response or polling systems. Students vote individually first, and then, if there is no prominent consensus, students talk in self-selected groups and revote, followed by an instructor debrief (for resources, see https://blog.peerinstruction .net). In PBL, course content is addressed through a series of relevant, authentic, open-ended problems (for examples, see www1.udel.edu/pblc). Students in permanent groups gather information on aspects of the problem, share findings at subsequent meetings, take a position based on their findings, and ultimately present their argument in some format. PBL is designed so that the question motivates learning and the structure develops students' self-regulation around their learning. In TBL, permanent, instructor-formed teams of students are held accountable for preparing for class via individual and team quizzes, and class time is devoted primarily to teams working on application exercises. Teams are also held accountable to each other through peer review (for more information, see www.teambasedlearning.org). In POGIL, students 
in instructor-formed groups learn essential, fundamental concepts through a guided cycle of inquiry that includes exploration, concept invention, and application. Students assume roles, and group activities lead students in constructing valid conclusions and inferring general principles from data (for examples, see https://pogil.org/resources). POGIL differs from the other formal pedagogies of PI, PBL, and TBL in that faculty may use it selectively to address specific concepts.

PLTL (Gosser et al., 2001) differs from the other approaches in that it uses cooperative- or collaborative-learning formats but occurs in additional sessions outside class time and uses peers to facilitate the group, thus introducing more coordination to group function (for resources, see https://pltlis.org). Research from student discourse in PLTL, however, can inform our understanding of group discourse in other formats as well. I have therefore included it in this discussion.

\section{COGNITIVE AND SOCIAL ASPECTS OF LEARNING IN GROUPS}

Working in groups can contribute both to students' affective and cognitive learning. Research on the outcomes from students participating in PBL, for example, shows robust positive effects on skills and affective outcomes, for example, ability to work in teams and attitude toward the profession (as reviewed in Albanese and Dast, 2014). In this discussion, however, I focus specifically on the role of collaborative experiences in promoting cognitive learning outcomes. Two perspectives are particularly useful in thinking through how group work affects cognitive learning: the cognitivist and the sociocultural (as discussed in Wood et al., 2014).

The cognitivist theory of learning focuses predominantly on what is going on in the mind of the individual and accords the environment primarily a passive part in that process. From a cognitivist view, for example, group work may act essentially as a catalyst for an individual's thought processes. Cognitivist approaches focus principally on ideas around the learner's access, use, accommodation, and reconciliation of prior knowledge with new knowledge and build on work by Piaget (1970) and Ausubel et al. (1978).

For example, theories of cognitive causes for the effectiveness of collaborative learning (as reviewed in Nokes-Malach et al., 2015) include the ideas that groups help individuals retrieve prior knowledge; extend their working memory capacity; and correct, supplement, and reinforce their knowledge. Groups presumably stimulate individuals to engage in known effective cognitive processes, such as accessing prior knowledge, retrieving ideas, and self-explaining (Halpern and Hakel, 2003;
Dunlosky et al., 2013; Brown et al., 2014). Self-explanation involves learners in generating their own understanding by connecting new ideas with background knowledge and filling in implicit references (Chi et al., 1989).

In contrast, sociocultural theories of learning credit the context as actively mediating individual cognition and draw largely from work by Vygotsky (1978) and Bakhtin (1981). In these theories, meaning is constructed through discourse, as participants either seek to conjoin their views to one truth or construct their understanding through exchange of ideas. Vygotsky posited that the most effective learning occurred at the zone of proximal development, that is, the difference between an individual's current level of development and that achievable through collaboration with a capable partner (Vygotsky, 1978, p. 86). From this theory, groups can foster the ability of individuals to think (cognition), and to think about their thinking (metacognition), in ways that they would not alone.

\section{A FRAMEWORK TO ANALYZE COGNITIVE ENGAGEMENT IN GROUP LEARNING}

Both the cognitivist and sociocultural perspectives of learning suggest that student engagement during group activities affects the outcomes of the experience. One tested model for student engagement that links student behaviors to proposed cognitive actions and outcomes is the ICAP framework (Chi, 2009; Chi and Wylie, 2014, and references therein). This framework can be construed as drawing from both cognitive and sociocultural theories of learning. Researchers are beginning to use this model to analyze collaborative-learning formats (Pluta et al., 2013; Wiggins et al., 2017).

In this hierarchical framework, different overt behaviors of learners link to different proposed knowledge-change (learning) processes and lead to different learning outcomes (Table 2). Each higher level of engagement subsumes characteristics of the modes below it. Students engaging passively, for example, primarily receive information. When engaging actively, however, students receive new information and activate prior knowledge, integrating both into an existing mental framework. When engaged constructively, students additionally generate and vet new ideas, and in the interactive mode they build on these activities with others. Throughout this discussion, I use the terms "passive," "active," "constructive," and "interactive" according to the specific definitions of the ICAP model (Table 2 ). These terms refer only to overt behaviors that can be documented. Students who appear passive, for example, may be actively or even constructively engaged mentally. As a broad tool, however, this framework is useful in exploring how group

TABLE 2. Key features of the ICAP framework of student engagement (as proposed and documented in Chi and Wylie, 2014)

\begin{tabular}{|c|c|c|c|c|}
\hline Category & Description & Knowledge-change process & Example behaviors & Cognitive outcomes \\
\hline Passive & Receiving & Storing & $\begin{array}{l}\text { Reading, listening or viewing without } \\
\text { note taking or other overt processing }\end{array}$ & Recall \\
\hline Constructive & Generating & $\begin{array}{l}\text { Inferring (integrating, comparing, } \\
\text { explaining, reflecting) }\end{array}$ & $\begin{array}{l}\text { Self-explaining, making concept maps, } \\
\text { taking notes of one's own }\end{array}$ & Transfer \\
\hline
\end{tabular}


formats affect student engagement and thus potential learning outcomes.

According to this model, both passive and active forms of engagement may help students store information, but only constructive and interactive modes promote students' abilities to infer and transfer ideas, leading to deeper, more robust learning. The active and constructive modes of engagement may be interpreted as aligning with cognitivist theory, in that group work can act primarily to activate an individual's mental processes. Students engaged interactively in this framework, however, are also benefiting from socially mediated learning. Effective interactive engagement requires not only that students share thoughts with each other, but also that these exchanges are constructive in nature and exhibit sufficient turn taking, for example, students interjecting to explain, critique, or elaborate. These processes can be affected by how activities are framed, how students interpret the activity prompt, and how group learning is assessed.

\section{HOW DO GROUPS SUPPORT STUDENT LEARNING?}

According to the ICAP framework, well-designed group learning can engage students constructively and interactively, resulting in higher-order cognitive learning outcomes. For example, studies in active-learning formats in physics showed that students' conceptual understanding increased compared with students in traditional lecture (Beichner et al., 2007). Presumably, during a fast-paced lecture, students are engaged primarily passively or actively, rather than constructively. The generative nature of constructive and interactive engagement during group pedagogies, however, likely contributes to students' connecting ideas more broadly. Another study in two sections of a nonmajors' biology course showed that students who work in groups perform better than those who work alone on higherorder test questions, though the same did not hold for lowerorder questions (Linton et al., 2014). According to the ICAP framework, students who engage passively or actively may glean lower-level learning, such as ability for recall or simple application, whereas only students who engage constructively and interactively achieve higher-order learning skills such as analysis and synthesis. In addition, studies in a chemistry laboratory setting showed that social situations in which students explain their choices and debate options with their peers (interactive behaviors) are most likely to cultivate students' metacognitive abilities of planning, monitoring, and evaluating strategies (Sandi-Urena et al., 2012).

Research on how students learn from answering conceptual clicker questions during PI in a large introductory genetics course (Smith et al., 2009) showed that the enhancement of learning from group discussion is apparently not caused simply by students accepting the correct answer from one of their peers. The authors looked at groups in which individual students all made incorrect choices on the original question. When asked a follow-up isomorphous question after discussion with their peers, these students were more likely to answer correctly. Thus, students learn from discussions with other students, even when no one in the group originally knows the correct answer. Looking at this result via the ICAP framework, receiving the answer from a peer involves an individual in, at best, active or constructive engagement. This study suggests that interactive engagement in peer discussions allowed students to build their understanding beyond that of any individual.

\section{WHY DO GROUPS SOMETIMES FAIL TO SUPPORT LEARNING?}

Both cognitive and social factors may contribute to the failure of collaborative groups to perform optimally (Nokes-Malach et al., 2015). According to the ICAP framework, any issues that interrupt students' abilities to constructively and interactively engage will diminish the positive outcomes of group learning. The primary factors that challenge interactive group learning include cognitive load aspects of group processing and social aspects of group dynamics.

Cognitive load challenges to participants during group learning can sabotage the effectiveness of this approach (reviewed in Nokes-Malach et al., 2015). The rapid switch of speaker and presentation of multiple perspectives can interrupt an individual's normal pattern of memory retrieval. These effects always mediate the effectiveness of group work, so that if group tasks are too easy-that is, the individual could successfully complete them alone-the group becomes a liability rather than an asset. On the other hand, groups allow the cognitive load of difficult tasks to be divided and scaffolded by the complementary knowledge of the members. However, task complexity can exceed the capabilities of even the group, and in that case, collaborative learning also presumably fails.

Social factors that affect group dynamics can affect the constructive and interactive engagement needed for higher-order learning. Students need to interact in ways that promote cocreation of knowledge, such as demonstrating supportive social behavior and encouraging and evoking processing of ideas (Johnson and Johnson, 1999). One possible obstacle in this regard is the student who dominates the discussion and disrupts robust interactive engagement.

In work by Eddy et al. (2015), international students in a biology class were more likely to report that their role in discussion was impacted by dominating students. A recent study (Theobald et al., 2017) in a large introductory biology class $(N$ = 684) examined how the type of activity affected students' performance, perceptions, and the group dynamic, including dominating students. In one case, students completed a three-section worksheet in groups, a "loosely structured task." In the second, "structured" condition, students first worked independently on one of the sections, then conferred with other students who had worked on the same section. Finally, these students dispersed to form a new group with students who had completed the other sections. This group then discussed the whole worksheet guided by prompts in a jigsaw activity. The authors explored student performance on pre/posttests, students' perceptions of working with a dominator or a friend, and their comfort level with the experience. Being comfortable in a group enhanced students' performance by $27.5 \%$, though being with a friend did not impact performance. Students who reported working with a dominator performed slightly less well on the posttest. Students felt less dominated (67\%), however, when working in the jigsaw activity. The authors proposed that setting up group work to encourage more positive interdependence, as in their jigsaw activity, helped mitigate group inequities. In addition, Wiggins et al. (2017) attributed the greater learning gains when using this jigsaw activity to its interactive dynamic per the ICAP model.

Grading practices and activity prompts can also affect the quality of student engagement. Students must feel that the 
interactive back-and-forth of discussion is both productive for them and valued by the instructor-for example, it enhances grades-in order to undertake this cognitively and socially demanding work. In studies of group discussions during PI clicker questions in undergraduate astronomy classes, students relied more on the most knowledgeable student and discussed questions less when they were being graded on the correct answer (James, 2006; James et al., 2008). Further studies in introductory astronomy and physics classes showed that grading only on participation enhanced the collaborative quality (James and Willoughby, 2011) or students' perceived quality (Turpen and Finkelstein, 2010) of the discussions, though it did not affect learning gains (Willoughby and Gustafson, 2009). In one study in upper-division undergraduate biology classes taught using PI, students largely did engage in quality discussion during peer discussion of clicker questions. Even so, when students were explicitly prompted to explain their answers during a group exercise, the quality of the discussion improved further (Knight et al., 2013).

\section{WHAT DOES STUDENT DISCOURSE TELL US ABOUT THEIR LEARNING IN GROUPS?}

Analyzing student conversations provides insights into ways that constructive and interactive engagement in the group mediates students' development of conceptual understanding, problem-solving skills, and understanding of disciplinary norms (e.g., Becker et al., 2013; Sawyer et al., 2013; for a review, see Jiménez-Aleixandre and Erduran, 2007). These learning goals also map onto developing students' abilities to explain and to argue. The distinction between an explanation and an argument may be important for thinking through the functions of group work and about the differences between constructive and interactive modes of engagement. Osborne and Patterson (2011) posit explanation and argument as two distinct entities in discourse. An explanation provides a reason or accounts for something, whereas an argument explores whether the explanation is useful and better than other options. This definition reminds us not only of the hierarchy in students' cognitive actions-lower-level recall and comprehension versus higher-order analysis, synthesis, and evaluation (Bloom and Krathwohl, 1956)-but may also capture a difference between constructive versus interactive engagement.

A sociocultural study of student discourse in a general chemistry course using PLTL (qualitative data from 15 groups of six to eight students), for example, showed that students in the groups talked in ways to cultivate a communal knowledge of chemistry; focused on the processes of complex problem solving, including weighing alternate perspectives; and developed abilities to regulate and reflect on their learning (Repice et al., 2016) - all of which are constructive behaviors. Some research on the effect of the type of activity on discourse in PLTL, however, notes the importance of directing students to compare and contrast differences, whether of systems or ideas or between predicted and actual behaviors, to stimulate deeper engagement in meaning-making (Young and Talanquer, 2013). Thus, prompting students to engage more interactively via argumentation is an important component of learning in groups. PLTL may offer the advantage of on-site peer leaders to stimulate this level of discourse.
An important construct in argumentation is decenteringmoving from framing ideas based only on one's own experience to taking into account other contexts, such as the social or scientific (Piaget, 1955, as discussed in Moon et al., 2017). This action also captures an aspect of the interactive mode of the ICAP model. Moon et al. (2017) studied student group discourse in two small physical chemistry classes that used POGIL. They conducted transcript analysis using Toulmin's argument model (Toulmin, 1958). This model categorizes argument as being composed of data, claim (the conclusion), and warrant (explanation connecting data to claim), with additional possible elements of backing, qualifiers, and rebuttal. They found that, when students lacked elements of decentering in their arguments, they were more likely to focus rebuttals and counterarguments simply on getting the "right" answer, rather than understanding what they were doing. Group discussions illustrated decentering when students used counterarguments and rebuttals to address perceived flaws in an argument and when they evaluated their own ideas in light of another's. This example further supports the importance of students not only engaging constructively (e.g., generating explanations), but also interactively (e.g., countering other opinions) to maximize learning in groups.

In PI and TBL, instructors provide questions for discussion that include a menu of choices from which students must select the best response-a closed system. The requirement for consensus is designed to encourage students to compare options and debate choices. Picking answers from a menu, however, may only require that students are active, accessing prior knowledge, rather than being interactive with the group. In this regard, several studies of PI discussions in astronomy or physics classes revealed that students' understanding may not map onto their answer choices. That is, students could choose the correct answer without correct understanding or the wrong answer while still having some understanding (James and Willoughby, 2011; Wood et al., 2014). This finding arose particularly in two situations: students voting based either on peer pressure or on extraneous cues (James and Willoughby, 2011). Extraneous cues might include the way the question was phrased or terms recently used by the instructor. In Wood et al. (2014), however, analysis of sample group dialogues showed that students often benefited from the group discussion whether or not it was reflected in their vote before or after the discussion (as expanded on below). This finding further corroborates those of Smith et al. (2009), discussed earlier, and supports the importance of interactive engagement in building students' knowledge.

Wood et al. (2014) studied a random sample of group conversations over time in a physics class taught using PI (20 distinct groups). They analyzed students' processes of conceptual learning as captured in student dialogues, drawing on the resources model of learning physics (Hammer et al., 2005). Specifically, they looked for evidence of change in students' conceptual thinking and then identified the mental resources that were activated that apparently triggered that change. These resources included knowledge elements, linkages between elements, or control structures (tacit epistemological frames that implicitly regulate what resources are activated). Linkages might include connecting scientific and everyday explanations or scientific concepts, for example. Sample student 
control structures include approaches such as mapping meaning to mathematics, pictorial analysis, and reiterative plug and chug. This work showed that students experienced conceptual change but that voting results might not accurately reflect student learning. Their findings demonstrated the importance of designing questions that activated students' higher-level cognitive resources and, presumably, urged them into interactive modes of engagement. They also note the value of instructors debriefing group discussion, providing their more expert epistemological framing to student deliberations.

\section{HOW DOES THE WAY GROUPS ARE FORMED AFFECT STUDENT OUTCOMES?}

Practitioners of group work often struggle with this question. Should students self-select into groups or should instructors form groups? How do group size and composition affect the functioning and learning in the group? Should group composition be permanent or changing throughout a term? Advice about these questions abounds based on instructor preference and instinct, but in fact, evidence informing these answers is scant and is discussed below. According to the ICAP model, instructors should form groups in a way most likely to foster interactive engagement.

A recent study looked at students' self-selection patterns into groups over the course of a term in a large introductory biology course $(N=700)$ taught using group work and PI (Freeman et al., 2017). The authors found that students did largely form groups according to like ethnicity and/or gender or class achievement. Similarly, in a study in a biology class, female students reported seeing less value to peer discussions unless they were in self-selected groups of their friends (Eddy et al., 2015). In terms of impact of the group composition on group performance, a study in introductory undergraduate biology classes found that, in the context of inquiry learning, groups that were homogeneous in terms of student ability were most effective (Jensen and Lawson, 2011).

On the other hand, if instructors form groups, is there an effect on student performance? Classic arguments (Davis, 2009) for instructor-formed groups include that self-selected groups can lack diversity, isolate shy or underrepresented students, and promote groupthink by prioritizing group cohesion. A study (Harlow et al., 2016) in a large $(N=690)$ introductory physics course looked at the question of how composition of instructor-formed groups affected student achievement. The authors divided students into variously composed groups and tracked individuals' performance gains on a validated instrument, the Force Concept Inventory (Hestenes et al., 1992). Groups were formed that differed in both composition and size, that is, those in which students were approximately of the same ability (based on precourse test score) or mixed ability, those that included one isolated woman, and those of sizes of three or four. They found no statistically significant differences in postcourse versus precourse inventory score gains for any of the groups. This result led the authors to surmise that there should be no effect on student performance when students worked in self-selected groups versus instructor-selected groups.

Although TBL proponents advocate for permanent, instructor-formed groups, PI practitioners typically allow students to work in random groups composed of whoever is sitting near. Research on student learning from PI classrooms is robust and indicates an overall enhancement of student learning when using this pedagogical format (Crouch and Mazur, 2001). One recent study in a class using PI, however, showed that, if students remained in permanent groups, they became more expert-like in their thinking, as measured by the Colorado Learning Attitudes about Science Survey (Zhang et al., 2017). Various aspects of learning theory likely contribute to this result, such as the ability of a cohesive team to promote more interactive engagement.

Students' identity issues can be important in group composition choices, especially if students face stereotype threat (Steele, 2010) or judgment by their peers. For this reason, best practices urge instructors to avoid isolating students of underrepresented demographics in groups. A group that may be invisible in this regard are the students who identify as lesbian, gay, bisexual, transgender, queer, intersex, and asexual (LGBTQIA). Few studies have focused on this group of students in STEM classrooms (Cech and Waidzunas, 2011). A qualitative exploratory study of the experiences of LGBTQIA students in an upper-level biology class involving extensive group work found that this pedagogy could impose additional stressors on these students (Cooper and Brownell, 2016). If LGBTQIA students were in groups with students they did not know or if the composition of groups changed during the course, they felt apprehensive about coming out in a context where they perceived that their identity was still not normalized. Further, the intersectionality of identities among students poses challenges in teaching in general, and group work in particular, that can be difficult to anticipate.

In general, viewing these studies through the lens of the ICAP framework, interactive engagement is more likely in groups of students who are comfortable with one another, either because they share some common ground or because they become cohesive over time. In the latter case, instructors may need to foster cohesion, as I discuss in the Implications for Practice section.

\section{DOES GROUP WORK SUPPORT OR DERAIL DIVERSITY EFFORTS?}

Is group work equally effective for all groups of students? Not necessarily, according to current research. Studies have shown that higher-achieving students benefit disproportionately in collaborative groups (Beichner et al., 2007; Jensen and Lawson, 2011). If these students more often assume the teaching role, they presumably spend more time in constructive modes of engagement. Other studies in a large biology class over several terms showed that more-structured formats (which included required preparation and in-class group discussions) helped all students, but positively affected outcomes disproportionately for economically or educationally disadvantaged students (Haak et al., 2011) or Black and first-generation students (Eddy and Hogan, 2014). One study linked the achievement outcomes for underrepresented minority students in classes taught with structured group work to these students' gain in confidence in their science ability (Ballen et al., 2017). On the other hand, studies in physics of the impact of Student-Centered Active Learning Environments with Upside-Down Pedagogies (SCALE-UP, a form of collaborative learning) on student learning outcomes showed that, although white and Black students' failure rates were significantly less in SCALE-UP classes compared with lecture-based classes, failure rates for Native American, Asian-American, and Hispanic students were not 
statistically different (Beichner et al., 2007). Students who face particular identity issues, as noted earlier, also may not always feel that group work is in their best interests, though how their learning may be affected has yet to be determined. These results may highlight cultural differences in expectations for, and comfort with, interactive engagement in groups.

\section{HOW DO LEARNING SPACES IMPACT GROUP WORK?}

Spaces are not neutral elements in the teaching and learning dynamic. Studies have shown that physical spaces elicit preconceived expectations of what should happen there (Gaffney et al., 2010; Brooks, 2012; Brooks and Solheim, 2014). Students' prior knowledge usually says that lecture halls are for lecture, for example, whereas round tables and movable chairs may signal that discussion will take place. These perceptions are likely to affect whether students engage interactively. As institutions are building active-learning classrooms (ALCs; movable round tables and chairs, flat floor, usually technology-enhanced), research is being compiled on the impact of those kinds of spaces on student learning (Baepler et al., 2016).

Two quasi-experimental studies isolated space as the only variable between two classes. Course, instructor, pedagogy (student centered), and in one case, time of day, were held constant; what changed was whether the course was taught in a traditional versus an active-learning classroom. Correcting for student variance in ACT scores, students in the active-learning spaces statistically outperformed those in the traditional-style classrooms (Brooks, 2011; Walker et al., 2011; Cotner et al., 2013). Part of the basis for this difference was the way that the space supported or detracted from the instructor's ability to implement the pedagogy. In addition, ALC spaces may better enable the social connections during group work that appear instrumental to interactive engagement and learning (Beichner et al., 1999).

Do the technological affordances of ALCs contribute to these positive learning outcomes? One quasi-experimental study examined an introductory biology course with sections conducted in a high-tech and a low-tech ALC. Controlling for student demographics, instructor, and pedagogy, student academic performance on a number of measures was not statistically different between the two sections (Soneral and Wyse, 2017). Student attitudes about the experience were comparable between the two sections, and students in the high-tech classroom did not note that the technology enhanced their experience. If technology use does not cultivate interactivity beyond low-tech formats, then students may not experience an added benefit.

\section{IMPLICATIONS FOR FUTURE RESEARCH How Do Students' Specific Roles in the Group Affect Individual Outcomes?}

One important gap in the data is how the quality of discussions ultimately affects individual student achievement. Classroom-based studies have yet to demonstrate how the role an individual student takes in discussions specifically impacts his/ her outcome. Do all students in the group need to make significant or specific kinds of contributions to the group to achieve consistent outcomes? Must students be actively involved in the verbal generation of explanations and alternate views to develop their understanding? In other words, does the ICAP model of engagement apply only to overt experiences, or can students benefit from tacit involvement? The answers to these questions are important in discerning the critical structural features of group work needed to maximize student achievement.

\section{How Does Group Work Affect Learning Outcomes for Special Needs Students?}

The growing population of undergraduate students with special needs, whether cognitive, emotional, physical, or psychologi$\mathrm{cal}$, also raises questions and poses challenges for instructors in implementing group work. Group activities put a spotlight on these students in ways that traditional lecture classes do not. The accommodations required for students with physical constraints, such as visual or auditory impairments, need to be incorporated into the activity plan and may change the flow of ideas throughout the group. On the other hand, the group interactions may enhance these students' sense of community and make them feel less isolated. Students with cognitive or emotional challenges, however, may struggle specifically with the interactive aspects of learning (Langford-Von Glahn et al., 2008; Knott and Taylor, 2014; Gonzalez, 2016). Importantly, these student groups are not homogeneous, but instantiate other aspects of diversity that further compound the issues (Tevis and Griffen, 2014). Typically, there are only small numbers of these students in any given study of undergraduate courses, and research results are lacking. Preliminary data on research with students with disabilities that call for accommodations such as quiet work spaces suggest that these students do benefit in group-learning environments (R. Beichner, personal communication, May 4, 2017). Much work, however, remains to be done.

\section{IMPLICATIONS FOR PRACTICE}

\section{Maximizing Cognitive Outcomes of Group Activities}

Cognitive load issues warrant instructors making the effort to ensure that their group activities align with the capabilities of the group. Noting students' behaviors during group work and analyzing performance on group assignments can provide insights on how well activities are matched to students' current levels of development. Ideally, exercises should push students just beyond their current comfort level and require them to work together, complementing one another's strengths and weaknesses. Whether instructors choose to use groups regularly or only occasionally, providing prompts to cue desirable group interaction is key. Instructors need to encourage students to debate choices, explain answers, and think about their own thinking and model these actions for students. This instruction may be especially critical in group methods such as PI and TBL that provide students with a ready-made menu of answer choices. The way the question is framed is critical to promoting particular mental processes. Beatty et al. (2006) thus propose a systematic approach to designing group questions (for PI clicker questions specifically) that allow questions to serve three goals: helping students learn concepts (content), learn how to think about content (cognitive), and learn how to think about how they are thinking (metacognitive). For additional suggestions see Table 3.

\section{Supporting the Group Process}

Instructors may need to cultivate the social comfort or cohesion necessary for robust interaction by devoting some effort to 
TABLE 3. Recommendations to optimize interactive engagement in group learning, with "interactive" being defined via the ICAP framework

\begin{tabular}{|c|c|c|}
\hline Plan & $\bullet$ & $\begin{array}{l}\text { Activities at the appropriate level of challenge for the } \\
\text { group } \\
\text { ○ Pose questions at level of analysis, synthesis, or } \\
\text { evaluation } \\
\text { ○ Use real-life examples or data } \\
\text { - Provide context-rich problems or case studies } \\
\text { Formation of comfortable or cohesive groups } \\
\text { - Let students self-select } \\
\text { - Form groups using transparent criteria } \\
\text { - Provide resources for team building }\end{array}$ \\
\hline Prompt & • & $\begin{array}{l}\text { Constructive interactions } \\
\circ \quad \text { Create group guidelines } \\
\circ \text { Assign roles in the group } \\
\circ \text { Articulate and model expected group interactions } \\
\text { Interactive engagement } \\
\circ \quad \text { Cue interaction in activity descriptions-e.g., } \\
\text { explain, compare, debate } \\
\text { - Provide sample language for civil disagreement } \\
\text { Model interactive exchanges in class debriefs by } \\
\quad \text { discussing options }\end{array}$ \\
\hline Promote & $\bullet$ & $\begin{array}{l}\text { Participation } \\
\circ \text { Assign roles in the group } \\
\circ \text { Random call } \\
\circ \text { Conduct peer review } \\
\text { Generative group processing by requiring products } \\
\text { from groups periodically } \\
\circ \quad \text { Collect worksheets } \\
\circ \quad \text { Use polling system responses } \\
\text { - Require case study or problem solutions with } \\
\quad \text { evidence or explanations }\end{array}$ \\
\hline Assess & $\bullet$ & $\begin{array}{l}\text { Participation } \\
\circ \quad \text { Random call during debriefs } \\
\circ \text { Conduct self and peer review } \\
\circ \quad \text { Consider individual quizzes after some group } \\
\text { discussions } \\
\text { Products from groups for evidence of interaction, not } \\
\text { primarily correctness } \\
\circ \quad \text { Require groups to explain their thinking, not just } \\
\text { provide answers } \\
\text { - Grade based on multiple perspectives analyzed } \\
\text { Encourage students to acknowledge one another's } \\
\quad \text { contributions }\end{array}$ \\
\hline
\end{tabular}

developing students' abilities to work in groups (Prichard et al., 2006). Groups that remain stable throughout the term help build a sense of connection among individuals in the group that encourages and supports students in participating. Creating team contracts at the outset and conducting peer review intermittently throughout the term will provide students with guidelines and feedback to develop the skills of this social dynamic, encouraging students to interact more meaningfully. Assigning roles promotes accountability to the group and pushes more students into interactive involvement in the discussions that may be critical to their deriving maximum benefit. Alternatively, randomly calling on group members during debriefs can encourage fuller participation and can also reduce potential gender bias in participation (Eddy et al., 2014). For additional evidence-based practices in scaffolding group learning, see Table 3 and Hodges (2017).

\section{Assessing Group Learning}

Constructive engagement is characterized by the generation of a product, either mental or physical. Thus, requiring tangible artifacts from group work, at least occasionally, may further encourage students to engage at higher levels (Table 3). Given that instructors want students to process ideas and examine options interactively, grading exclusively for correctness of responses may not encourage productive group interactions, as noted in the studies discussed earlier in the context of PI. The emphasis on peer review as part of the grading in TBL (Michaelsen et al., 2004) encourages and rewards students for engaging in productive, interactive discourse.

\section{CONCLUDING THOUGHTS}

Faculty use of active learning such as group work does not automatically ensure improved student learning outcomes or satisfaction (Andrews et al., 2011). For example, faculty often do not implement the structured pedagogies as designed, possibly nullifying some of the effects and wasting their efforts (Borrego et al., 2013; Dancy et al., 2016). Faculty workload issues combined with negative experiences with these strategies mean that faculty who try active-learning approaches may not persist (Henderson et al., 2012). The more we know about what aspects of group learning are necessary for cultivating specific learning, the more we can determine what constitutes essential, effective, and efficient practice, thus providing faculty with constructive guidelines to support their work and affirm their efforts.

\section{REFERENCES}

Albanese, M. A., \& Dast, L. (2014). Problem-based learning: Outcomes evidence from the health professions. Journal on Excellence in College Teaching, 25(3-4), 239-252. Retrieved April 5, 2018, from https://celt.miamioh.edu/ ject/

Andrews, T. M., Leonard, M. J., Colgrove, C. A., \& Kalinowski, S. T. (2011). Active learning not associated with student learning in a random sample of college biology courses. CBE-Life Sciences Education, 10, 394-405. https://doi.org/10.1187/cbe.11-07-0061

Ausubel, D. P., Novak, J. D., \& Hanesian, H. (1978). Educational psychology: A cognitive view. (2nd ed.). New York: Holt, Rinehart and Winston.

Baepler, P., Walker, J. D., Brooks, D. C., Saichaie, K., \& Petersen, C. I. (2016). A guide to teaching in the active learning classroom: History, research, and practice. Sterling, VA: Stylus.

Bakhtin, M. M. (1981). In Holquist, M., Emerson, C., \& Holquist, M. (Eds.), The dialogic imagination: Four essays by M. M. Bakhtin. Austin: University of Texas Press.

Ballen, C. J., Wieman, C., Salehi, S., Searle, J. B., \& Zamudio, K. R. (2017) Enhancing diversity in undergraduate science: Self-efficacy drives performance gains with active learning. CBE-Life Sciences Education, 16, ar56. https://doi.org/10.1187/cbe.16-12-0344

Beatty, I. D., Gerace, W. J., Leonard, W. J., \& Dufresne, R. J. (2006). Designing effective questions for classroom response system teaching. American Journal of Physics, 74(1), 31-39. https://doi.org/10.1119/1.2121753

Becker, N., Rasmussen, C., Sweeney, G., Wawro, M., Towns, M., \& Cole, R. (2013). Reasoning using particulate nature of matter: An example of a sociochemical norm in a university-level physical chemistry class. Chemical Education Research and Practice, 14, 81-94. https://doi.org/ 10.1039/C2RP20085F

Beichner, R., Bernold, L., Burniston, E., Dail, P., Felder, R., Gastineau, J., \& Risley, J. (1999). Case study of the physics component of an integrated 
curriculum. American Journal of Physics, 67, S16-S24. https://doi .org/10.1119/1.19075

Beichner, R. J., Saul, J. M., Abbott, D. S., Morse, J. J., Deardorff, D., Allain, R. J., \& Risley, J. S. (2007). Student-Centered Activities for Large Enrollment Undergraduate Programs (SCALE-UP) project. In Redish, E., \& Cooney, P. (Eds.), Research-based reform of university physics (pp. 1-42). College Park, MD: American Association of Physics Teachers.

Bloom, B. S., \& Krathwohl, D. R. (1956). Taxonomy of educational objectives: The classification of educational goals, by a committee of college and university examiners. Handbook 1: Cognitive domain. New York: Longman.

Borrego, M., Cutler, S., Prince, M., Henderson, C., \& Froyd, J. E. (2013). Fidelity of implementation of research-based instructional strategies (RBIS) in engineering science courses. Journal of Engineering Education, 102(3), 394-425. https://doi.org/10.1002/jee.20020

Brooks, D. C. (2011). Space matters: The impact of formal learning environments on student learning. British Journal of Educational Technology. 42(5), 719-726. https://doi.org/10.1111/j.1467-8535.2010.01098.x

Brooks, D. C. (2012). Space and consequences: The impact of different formal learning spaces on instructor and student behavior. Journal of Learning Spaces, 1(2). Retrieved April 5, 2018, from https://libjournal uncg.edu/jls/article/view/285

Brooks, D. C., \& Solheim, C. A. (2014). Pedagogy matters, too: The impact of adapting teaching approaches to formal learning environments on student learning. In Baepler, P., Brooks, D. C., \& Walker, J. D. (Eds.), New directions for teaching and learning (Vol. 137: Active learning spaces) (pp. 53-61). San Francisco: Jossey-Bass.

Brown, P. C., Roediger, H. L. III, \& McDaniel, M. A. (2014). Make it stick: The science of successful learning. Cambridge, MA: Belknap Press of Harvard University Press

Bruffee, K. A. (1999). Collaborative learning: Higher education, interdependence, and the authority of knowledge (2nd ed.). Baltimore, MD: Johns Hopkins University Press.

Cech, E. A., \& Waidzunas, T. J. (2011). Navigating the heteronormativity of engineering: The experiences of lesbian, gay, and bisexual students. Engineering Studies, 3, 1-24. https://doi.org/10.1080/19378629.2010.545065

Chi, M. T. H. (2009). Active-constructive-Interactive: A conceptual framework for differentiating learning activities. Topics in Cognitive Science, 1 73-105.

Chi, M. T. H., Bassok, M., Lewis, M. W., Reimann, P., \& Glaser, R. (1989). Self-explanations: How students study and use examples in learning to solve problems. Cognitive Science, 13, 145-182. https://doi.org/10.1207/ s15516709cog1302_1

Chi, M. T. H., \& Wylie, R. (2014). The ICAP framework: Linking cognitive engagement to active learning outcomes. Educational Psychologist, 49(4), 219-243. https://doi.org/10.1080/00461520.2014.965823

Cooper, K. M., \& Brownell, S. E. (2016). Coming out in class: Challenges and benefits of active learning in a biology classroom for LGBTQIA students. CBE-Life Sciences Education, 15(3), ar37. https://doi.org/10.1187/ cbe.16-01-0074

Cotner, S., Loper, J., Walker, J. D., \& Brooks, D. C. (2013). It's not you, it's the room: Are high-tech, active learning classrooms worth it? Journal of College Science Teaching, 42(6), 82-88. https://doi.org/10.2505/4/ jcst13_042_06_82

Crouch, C. H., \& Mazur, E. (2001). Peer instruction: Ten years of experience and results. American Journal of Physics, 69(9), 970-977. https://doi.org/ 10.1119/1.1374249

Dancy, M., Henderson, C., \& Turpen, C. (2016). How faculty learn about and implement research-based instructional strategies: The case of peer instruction. Physical Review Special Topics-Physics Education Research, 12(1), 010110. https://doi.org/10.1103/PhysRevPhysEducRes 12.010110

Davis, B. G. (2009). Tools for teaching (2nd ed.). San Francisco: Jossey-Bass.

Dunlosky, J., Rawson, K. A., Marsh, E. J., Nathan, M. J., \& Willingham, D. T. (2013). Improving students' learning with effective learning techniques: Promising directions from cognitive and educational psychology. Psychological Science in the Public Interest, 14(1), 4-58. https://doi.org/ $10.1177 / 1529100612453266$
Eddy, S. L., Brownell, S. E., Thummaphan, P., Lan, M.-C., \& Wenderoth, M. P. (2015). Caution, student experience may vary: Social identities impact a student's experience in peer discussion. CBE-Life Sciences Education, 14, ar45. https://doi.org/10.1187/cbe.15-05-0108

Eddy, S. L., Brownell, S. E., \& Wenderoth, M. P. (2014). Gender gaps in achievement and participation in multiple introductory biology classrooms CBE-Life Sciences Education, 13, 478-492. https://doi.org/10.1187/ cbe.13-10-0204

Eddy, S. L., \& Hogan, K. A. (2014). Getting under the hood: How and for whom does increasing course structure work? CBE-Life Sciences Education, 13, 453-468. https://doi.org/10.1187/cbe.14-03-0050

Felder, R. M., \& Brent, R. (2016). Teaching and learning STEM: A guide for faculty. San Francisco: Jossey-Bass.

Freeman, S., Eddy, S. L., McDonough, M., Smith, M. K., Okoroafor, N., Jordt H., \& Wenderoth, M. P. (2014). Active learning increases student performance in science, engineering, and mathematics. Proceedings of the National Academy of Sciences USA, 111(23), 8410-8415. https://doi.org/ 10.1073/pnas.1319030111

Freeman, S., Theobald, R., Crowe, A. J., \& Wenderoth, M. P. (2017). Likes attract: Students self-sort in a classroom by gender, demography, and academic characteristics. Active Learning in Higher Education, 18(2), 115-126. https://doi.org/10.1177/1469787417707614

Gaffney, J. D. H., Gaffney, A. L. H., \& Beichner, R. J. (2010). Do they see it coming? Using expectancy violation to gauge the success of pedagogical reforms. Physical Review Special Topics-Physics Education Research, 6, 010102. https://doi.org/10.1103/PhysRevSTPER.6.010102

Gonzalez, F. (2016). For some, active learning can be a nightmare. ASEE Prism, 26(4), 52.

Gosser, D. K., Cracolice, M., Kampmeier, J. A., Roth, V., Strozak, V. S., \& Varma-Nelson, P. (2001). Peer-led team learning: A guidebook. Upper Saddle River, NJ: Prentice Hall.

Haak, D. C., HilleRisLambers, J., Pitre, E., \& Freeman, S. (2011). Increased structure and active learning reduce the achievement gap in introductory biology. Science, 332(6034), 1213-1216. https://doi.org/10.1126/ science. 1204820

Hake, R. R. (1998). Interactive-engagement vs. traditional methods: A six-thousand-student survey of mechanics test data for introductory physics courses. American Journal of Physics, 66, 64-74. https://doi.org/ 10.1119/1.18809

Halpern, D. F., \& Hakel, M. (2003). Applying the science of learning to the university and beyond: Teaching for long-term retention and transfer Change, 35(4), 36-41. https://doi.org/10.1080/00091380309604109

Hammer, D., Elby, A., Scherr, R., \& Redish, E. F. (2005). Resources, framing, and transfer. In Mestre, J. P. (Ed.), Transfer of learning from a modern multidisciplinary perspective (pp. 89-119). Greenwich, CT: Information Age Publishing.

Harlow, J. J. B., Harrison, D. M., \& Meyertholen, A. (2016). Effective student teams for collaborative learning in an introductory university physics course. Physical Review Special Topics-Physics Education Research, 12, 010138. https://doi.org/10.1103/PhysRevPhysEducRes.12.010138

Henderson, C., Dancy, M., \& Niewiadomska-Bugaj, M. (2012). The use of research-based instructional strategies in introductory physics: Where do faculty leave the innovation-decision process? Physical Review Special Topics-Physics Education Research, 8(2), 020104. https://doi.org/ 10.1103/PhysRevSTPER.8.020104

Hestenes, D., Wells, M., \& Swackhamer, G. (1992). Force Concept Inventory Physics Teacher, 30, 141-158. https://doi.org/10.1119/1.2343497

Hodges, L. C. (2015). Teaching undergraduate science: A guide to overcoming obstacles to student learning. Sterling, VA: Stylus.

Hodges, L. C. (2017). Ten research-based steps to effective group work (IDEA Paper \#65). Retrieved April 5, 2018, from www.ideaedu.org/Portals/0/ Uploads/Documents/IDEA\%20Papers/IDEA\%20Papers/PaperIDEA_65.pdf

James, M. C. (2006). The effect of grading incentive on student discourse in peer instruction. American Journal of Physics, 74(8), 689-691. https:// doi.org/10.1119/1.2198887

James, M. C., Barbieri, F., \& Garcia, P. (2008). What are they talking about? Lessons learned from a study of peer instruction. Astronomy Education Review, 7(1), 37-43. https://doi.org/10.3847/AER2008004 
James, M. C., \& Willoughby, S. (2011). Listening to student conversations during clicker questions: What you have not heard might surprise you! American Journal of Physics, 79, 123-132. https://doi.org/ 10.1119/1.3488097

Jensen, J. L., \& Lawson, A. (2011). Effects of collaborative group composition and inquiry instruction on reasoning gains and achievement in undergraduate biology. CBE-Life Sciences Education, 10(1), 64-73. https:// doi.org/10.1187/cbe.10-07-0089

Jiménez-Aleixandre, M. P., \& Erduran, S. (2007). Argumentation in science education: An overview. In Erduran, S., \& Jiménez-Aleixandre, M. P. (Eds.) Argumentation in science education (Science \& technology education library, vol. 35) (pp. 3-27). Dordrecht, Netherlands: Springer

Johnson, D. W., \& Johnson, R. T. (1999). Learning together and alone: Cooperative, competitive, and individualistic learning (5th ed.). Boston: Allyn \& Bacon.

Johnson, D. W., Johnson, R. T., \& Smith, K. A. (1998). Cooperative learning returns to college: What evidence is there that it works? Change, 30(4), 26-35. https://doi.org/10.1080/00091389809602629

Knight, J. K., Wise, S. B., \& Southard, K. M. (2013). Understanding clicker discussions: Student reasoning and the impact of instructional cues. CBELife Sciences Education, 12(4), 645-654. https://doi.org/10.1187// cbe.13-05-0090

Knott, F., \& Taylor, A. (2014). Life at university with Asperger syndrome: A comparison of students and staff perspectives. International Journal of Inclusive Education, 18(4), 411-426. https://doi.org/10.1080/13603116 .2013 .781236

Kober, N. (2015). Reaching students: What research says about effective instruction in undergraduate science and engineering. Washington, DC: National Academies Press.

Langford-Von Glahn, S. J., Zakrajsek, T., \& Pletcher-Rood, S. (2008). Teaching students with Asperger syndrome (and other disabilities) in the college classroom: Creating an inclusive learning environment. Journal on Excellence in College Teaching, 19(2-3), 107-133.

Linton, D. L., Farmer, J. K., \& Peterson, E. (2014). Is peer interaction necessary for optimal active learning? CBE-Life Sciences Education, 13, 243-252. https://doi.org/10.1187/cbe.13-10-0201

Mazur, E. (1997). Peer instruction: A user's manual. Upper Saddle River, NJ: Prentice Hall.

Michaelsen, L. K., Knight, A. B., \& Fink, L. D. (2004). Team-based learning: A transformative use of small groups in college teaching. Sterling, VA: Stylus.

Millis, B., \& Cottell, P. (1998). Cooperative learning for higher education faculty. Phoenix, AZ: Oryx.

Moog, R. S., \& Spencer, J. N. (2008). POGIL: Process Oriented Guided Inquiry Learning (ACS symposium series 994). Washington, DC: American Chemical Society

Moon, A., Stanford, C., Cole, R., \& Towns, M. (2017). Decentering: A characteristic of effective student-student discourse in inquiry-oriented physical chemistry classrooms. Journal of Chemical Education, 94, 829-836. https://doi.org/10.1021/acs.jchemed.6b00856

Nokes-Malach, T. J., Richey, J. E., \& Gadgil, S. (2015). When is it better to learn together? Insights from research on collaborative learning. Educational Psychology Review, 27, 645-656. https://doi.org/10.1007/s10648-015-9312-8

Osborne, J. F., \& Patterson, A. (2011). Scientific argument and explanation: A necessary distinction. Science Education, 95(4), 627-638. https:// doi.org/10.1002/sce.20438

Piaget, J. (1955). The language and thought of the child. Cleveland, $\mathrm{OH}$ Meridian.

Piaget, J. (1970). Piaget's theory. In Mussen, P. H. (Ed.), Carmichael's manual of child psychology. New York: Wiley.

Pluta, W. J., Richards, B. F., \& Mutnick, A. (2013). PBL and beyond: Trends in collaborative learning. Teaching and Learning in Medicine, 25(Suppl 1) S9-S16. https://doi.org/10.1080/10401334.2013.842917

Prichard, J. S., Bizo, L. A., \& Stratford, R. J. (2006). The educational impact of team-skills training: Preparing students to work in groups. British Journal of Educational Psychology, 76, 119-140. https://doi.org/10.1348/ $000709904 \times 24564$

Repice, M. D., Sawyer, R. K., Hogrebe, M. C., Brown, P. L., Luesse, S. B., Gealy, D. J., \& Frey, R. (2016). Talking through the problems: A study of discourse in peer-led small groups. Chemistry Education Research and Practice, 17, 555-568. https://doi.org/10.1039/c5rp00154d

Sandi-Urena, S., Cooper, M., \& Stevens, R. (2012). Effect of cooperative and problem-based lab instruction on metacognition and problem-solving skills. Journal of Chemical Education, 89(6), 700-706. https://doi.org/ 10.1021/ed1011844

Sawyer, K., Frey, R., \& Brown, P. (2013). Knowledge building discourse in peerled team learning (PLTL) groups in first-year general chemistry. In Suthers, D. D., Lund, K., Rosé, C. P., Teplovs, C., \& Law, N. (Eds.), Productive multivocality in the analysis of group interactions (Computer-supported collaborative learning series) (pp. 191-204). New York: Springer.

Smith, M. K., Wood, W. B., Adams, W. K., Wieman, C., Knight, J. K., Guild, N., \& $\mathrm{Su}, \mathrm{T}$. T. (2009). Why peer discussion improves student performance on in-class concept questions. Science, 323(5910), 122-124. https://doi.org/ 10.1126/science.1165919

Soneral, P. A. G., \& Wyse, S. A. (2017). A SCALE-UP mock-up: Comparison of student learning gains in high- and low-tech active-learning environments. CBE-Life Sciences Education, 16(1), ar12. https://doi.org/10.1187/ cbe.16-07-0228

Springer, L., Stanne, M. E., \& Donovan, S. S. (1999). Effects of small-group learning on undergraduates in science, mathematics, engineering, and technology: A meta-analysis. Review of Educational Research, 69(1), 21-51. https://doi.org/10.3102/00346543069001021

Steele, C. (2010). Whistling Vivaldi: How stereotypes affect us and what we can do. New York: Norton.

Tevis, T., \& Griffen, J. (2014). Absent voices: Intersectionality and college students with physical disabilities. Journal of Progressive Policy \& Practice 2(3), 239-254

Theobald, E. J., Eddy, S. L., Grunspan, D. Z., Wiggins, B. L., \& Crowe, A. J. (2017). Student perception of group dynamics predicts individual performance: Comfort and equity matter. PLOS One, 12(7), e0i8i336. https:// doi.org/10.1371/journal.pone.0181336

Toulmin, S. (1958). The uses of argument. Cambridge, UK: Cambridge University Press

Turpen, C., \& Finkelstein, N. D. (2010). The construction of different class room norms during peer instruction: Students perceive differences. Physical Review Special Topics-Physics Education Research, 6, 020123 https://doi.org/10.1103/PhysRevSTPER.6.020123

Vernon, D. T. A., \& Blake, R. L. (1993). Does problem-based learning work? A meta-analysis of evaluative research. Academic Medicine, 68, 550-563. https://doi.org/10.1097/00001888-199307000-00015

Vygotsky, L. S. (1978). Mind in society: The development of higher psychological process. Cambridge, MA: Harvard University Press.

Walker, J. D., Brooks, D. C., \& Baepler, P. (2011). Pedagogy and space: Empirical research in new learning environments. EDUCAUSE Quarterly, 34(4). Retrieved from https://er.educause.edu/articles/2011/12/pedagogy-and -space-empirical-research-on-new-learning-environments

Wiggins, B. L., Eddy, S. L., Grunspan, D. Z., \& Crowe, A. J. (2017). The ICAP active learning framework predicts the learning gains observed in intensely active classroom experiences. AERA Open, 3(2), 1-14. https:// doi.org/10.1177/2332858417708567

Wilkerson, L., \& Gijselaers, W. H. (1996). Bringing problem-based learning to higher education: Theory and practice. San Francisco: Jossey-Bass.

Willoughby, S. D., \& Gustafson, E. (2009). Technology talks: Clickers and grading incentive in the large lecture hall. American Journal of Physics, 77(2), 180-183. https://doi.org/10.1119/1.3013542

Wood, A. K., Galloway, R., Hardy, J., \& Sinclair, C. (2014). Analyzing learning during peer instruction dialogues: A resource activation framework. Physical Review Special Topics-Physics Education Research, 10(2), 020107. https://doi.org/10.1103/PhysRevSTPER.10.020107

Young, K. K., \& Talanquer, V. (2013). Effects of different types of small-group activities on students' conversations. Journal of Chemical Education, 90, 1123-1129. https://doi.org/10.1021/ed400049a

Zhang, P., Ding, L., \& Mazur, E. (2017). Peer Instruction in introductory physics: A method to bring about positive changes in students' attitudes and beliefs. Physical Review Special Topics-Physics Education Research, 13(1), 010104. https://doi.org/10.1103/PhysRevPhysEducRes.13.010104 